\title{
Developing Digital Story Telling and Educational Games to Improve Early Childhood Cognitive Ability
}

\author{
Ditta Manullang ${ }^{1, *}$ Humuntal Banjarnahor ${ }^{2}$ Lisbet Simanjuntak $^{3}$
}

\author{
${ }^{1}$ Post graduate of Educational Management Department, Universitas Negeri Medan, Indonesia \\ ${ }^{2}$ Lecturer of Educational Management Department, Universitas Negeri Medan, Indonesia \\ ${ }^{3}$ Senior Trainer of Regional Office of Early Childhod Education and Community Education Development in North \\ Sumatera Province, Indonesia \\ *Corresponding author. Email: ditta.manullang@kemdikbud.go.id
}

\begin{abstract}
This study aims to produce a development of a digital literacy learning model using digital story telling media and educational game applications so that there is an increase in the cognitive abilities of early childhood with the support of teachers and parents. The research was carried out in Pembina State Kindergarten, Porsea District, Toba Regency, Early Childhood Education of Tamawi and Early Childhood Education of Al Barokah in Langkat Regency, using a research and development design as proposed by Borg and Gall (2003: 624). The research design used in this study was a one group pretest posttest design. The technique for collecting data in this study was to use observation, tests and documentation. The results showed that there was a significant effect on 45 early childhood children in Pembina State Kindergarten Porsea, Early Childhood Education of Tamawi and Early Childhood Education of AL Barokah Langkat Regency who carried out digital literacy learning using digital story telling and educational games on cognitive development, this can be seen from the increase from pre-test scores to post-test scores before and after treatment.Thus, it can be concluded that the development of digital literacy learning models using digital story telling and educational game applications can improve the cognitive abilities of early childhood.
\end{abstract}

Keywords : Digital Literacy,Digital Story Telling, Game Application, Early Childhood Education.

\section{INTRODUCTION}

The development of technology and information has brought the current generation into the world of digital literacy. Digital literacy has become a familiar thing, both in the academic and non-academic fields. One alternative related to digital literacy is the switch from physical reading materials to digital ones. In everyday life, internet users under the age of 10 are also common. In various public spaces such as shopping centers, restaurants, and airports, children aged 3-9 years old are often found busy with gadgets, either mobile phones or tablets. They use these gadgets to access games or movies via the internet. When dealing with the internet, children also show a tendency to adapt more easily to digital technology compared to adults in responding to this condition, some parents actually feel proud when their very young children are able to operate computers and other gadgets. These parents also do not hesitate to buy or lend laptops, tablets, or mobile phones to their children [10].
Digital literacy is the ability to use information and communication technology (ICT) to find, evaluate, utilize, create and communicate content or information with cognitive, ethical, social emotional and technical or technological aspects [17]. Digital literacy according to Potter [19] is an individual's interest, attitude, and ability to use digital technology and communication tools to access, manage, integrate, analyze and evaluate information, build new knowledge, create and communicate with others in order to participate effectively in society [24]. Furthermore, according to Gamire and Pearson [8] digital literacy is the ability to read, write, and calculate various digital texts/objects that exist in a digital environment. The question is, what is the text/object and digital environment? Humans basically live in three domains, namely: the natural world (everything on the surface of the earth that exists without human intervention and invention), the social world (all systems created by humans for their collective life), and the designed world (the result of human modification of the environment). natural world and social world). One 
form of the designed world is information and communication technology created by humans to collect, manipulate, classify, store, and distribute information.

The era of the industrial revolution 4.0 makes early childhood inseparable from the influence of technology, especially the use of gadgets [3]. This means that if children are able to read and write from an early age, they will learn the environment faster. Therefore, efforts to develop early literacy are an urgent need. This requires strategies to accelerate early childhood literacy skills. Data shows that $12 \%$ of children are familiar with the internet at the age of 5 years, $4 \%$ at the age of 4 years, and $1 \%$ at the age of 3 years [5]. From the research findings, it can be seen that internet users are young and even their introduction to the internet begins at the age of toddlers. The interaction of children aged 3 to 12 years with the internet is generally mediated by the people around them. People who have a role in introducing the internet to children for the first time include: their parents (45\%), other family members other than parents such as older brothers, cousins or uncles, and aunts (29\%), teachers $(11 \%)$, and friends $(2 \%), 10 \%$ of children who stated that they were self-taught self-taught. Sucipto and Nuril [21] stated that $27 \%$ of children aged two years have been introduced to gadgets, and $54 \%$ of parents allow children aged 3-4 years to use gadgets, for the reasons: 1) so that children are familiar with technology from an early age, 2) so that children are not fussy 3 ) their children's friends are already using gadgets.

The digital era that is currently developing is expected to be able to spur students to utilize digital literacy in the academic field. One of the advantages that can be taken from this digital era is that school residents can access up to date educational information. This activity can be carried out by utilizing digital media, such as computers, laptops, or smartphones that are connected to the internet network that can be easily accessed. by students. However, the lack of knowledge about digital literacy is a serious obstacle in its application. One of the efforts that can be done is to equip students with digital literacy skills to extract digital information wisely.

On the other hand, there is a positive role for gadgets in early literacy programs such as the applications contained in gadgets are very innovative, for example in drawing, learning arithmetic or mathematics, watching drama story telling or folklore without them being busy bothering their parents. As time goes by, if this is later accustomed to, it is not uncommon for children to be unable to develop their perceptual powers based on what they see, hear and feel in the future, so that children do not have a complete and comprehensive understanding, children are also felt unable to train their memories of all events and events. events that have been experienced, then the child becomes unable to develop his thoughts in order to relate one event to another, the child is unable to understand the symbols scattered in the world around him, and the child is unable to do reasoning, both naturally occurring (spontaneous), as well as through a scientific process (experimental) and what is even worse is that the child is unable to solve the life problems he faces, so that in the end the child will become an individual who is unable to help himself.

Related to the review above, digital literacy needs to be embedded in a structured learning process, or at least integrated with the learning process. The goal is that there is control over the use of digital media. These skills must be accommodated in the classroom and school environment, so they must be utilized optimally for cognitive, social, language, visual, and spiritual skills. Beside that Daryanto [7] which states that the learning materials contained in it must be in accordance with the curriculum and contain many benefits. The fiveteen minute activity of reading non-lesson books in digital literacy actually refers to efforts to familiarize students with reading. However, with the implementation of digital literacy, it is expected to provide more benefits for institutions, especially students, to be able to spread ideas and find sources of information that can be accounted for. In addition, the use of digital literacy is believed to be able to provide creative, innovative, and contemporary learning innovations. Therefore, digital literacy is needed in society, especially early childhood. The experience of early childhood literacy is believed to form a strong foundation for reading development [15]. Knowledge, skills, and attitudes of early childhood that form the basis of reading and writing are called early literacy skills [23].

On March 24, 2020, the Minister of Education and Culture of the Republic of Indonesia issued Circular Letter Number 4 of 2020 concerning the Implementation of Education Policies in the Emergency Period for the Spread of Covid-19. The Circular explains that the learning process is carried out at home through online/distance learning to provide a meaningful learning experience for students. Studying at home can be focused on life skills education, including regarding the Covid-19 pandemic.

The role of teachers and parents is highly expected in such a situation, the synergy between parents and children will produce optimal literacy for children in their development period. Early Literacy is a strong and appropriate foundation in addressing the various problems that have been described and the initial step of lifelong learning in the current Information era, and must be one of the concerns in order to make an optimal contribution to the education process because lifelong learning has become an integral part of the education system in developed countries. So, it is not an exaggeration to say that the concept of lifelong learning has become the embryo of the birth of a strong learning culture (including reading culture) in people's lives and the realization of a more literate generation. 
Based on the explanation above, it can be seen that in providing stimulation to children, it must be in accordance with the characteristics of children who are oriented towards fun activities. The methods and media used are important factors in fulfilling enjoyable literacy activities. Levie and Lentz [14], which states the functions of learning media are:

- The function of attention is to attract and direct students' attention to concentrate on the content of the lesson related to the visual meaning displayed or accompanying the text of the subject matter or the lesson is one of the lessons that they do not like so that they do not pay attention.

- The affective function can be seen from the enjoyment of students when learning (reading) illustrated texts.

- Cognitive function can be seen from research findings which reveal that visual symbols facilitate the achievement of goals to understand and remember information or messages contained in images.

- The compensatory function can be seen from the results of the study that visual media help students who are weak in reading to organize information in the text and recall it.

Therefore, this study tries to implement a stimulation program for children at home and at school with methods and media that are suitable for children's characteristics. The program is intended to be in the form of providing digital literacy packages consisting of guides for digital literacy activities, and digital literacy media in the form of digital story telling and educational game applications.

Mursid [18] explains that early childhood education is a form of education that is more focused on providing basic physical growth and development, and also as a forum for providing stimulation and stimulation for the development of the potentials contained in children. Asmawati [2] stated that early childhood education is the implementation of education that is carried out as the basis for the formation of the human personality as a whole, namely for the formation of character, noble character, intelligent, cheerful, skilled, and pious to God Almighty.

So it can be concluded that Early Childhood Education can be interpreted as a form of providing education that focuses on laying the foundation for growth and development, both motor coordination (fine and gross), emotional intelligence, multiple intelligences (multiple intelligences) and spiritual intelligence, in accordance with uniqueness and growth of early childhood.

According to Paul Gilster [9] digital literacy is the ability to understand and use information in many formats from various sources when it is presented through a computer. Meanwhile, Common Sense media
[6] states that digital literacy includes three abilities, namely competence in using technology; use and understand digital content and assess its credibility, as well as how it is created; research and communicate with the right tools. Keengwe \& Georgina [12] in their research which has stated that technological developments provide changes to the implementation of teaching and learning. Information technology can be accepted as a medium in carrying out the educational process, including helping the teaching and learning process, which also involves searching for references and sources of information [22].

Based on Minister of Education and Culture Regulation number 137 of 2014 [11], the level of achievement of children's development in aspects of cognitive development is divided into:

1. Learning and problem solving consists of four indicators, namely (a) showing exploratory and probing activities (such as what happens when water is spilled); (b) solving simple problems in everyday life in a flexible and socially acceptable manner; (c) applying knowledge or experience in new contexts; (d) showing a creative attitude in solving problems (ideas, ideas, out of the ordinary);

2. To think logically, there are eight indicators, namely; (a) recognize differences by size: "more than"; "less than"; and "most/most"; (b) showing initiative in choosing the theme of the game (such as: "let's play pretend like birds"; (c) planning activities to be carried out; (d) recognizing cause and effect about the environment ( blowing wind causes leaves to move, water can cause something to get wet); (e) classify objects based on color, shape, and size "three variations"; (f) classify more objects into the same or similar groups, or paired groups with more than "two variations"; (g) recognize the $A B C D-A B C D$ pattern; (h) sort objects by size from smallest to largest or vice versa.

3. For symbolic thinking, there are five indicators of achievement, namely (a) mentioning the symbols of numbers 1-10; (b) use number symbols to calculate; (c) match numbers with number symbols; (d) recognize various symbols of vowels and consonants; (e) present various kinds in the form of pictures or writing (there are pencil objects followed by writing and pencil drawings.

\section{METHOD}

Develop Digital Story Telling and Educational Games to Improve Early Childhood Cognitive Ability using research and development (R\&D) developed by Borg \& Gall [4] that stated educational research and development is a process used to develop and validate educational products. 
The research design used in this study was a one group pretest posttest design. In this design, before the treatment is given, the sample is given a pretest (initial test) and at the end of the study the sample is given a posttest (final test). This design is used in accordance with the objectives to be achieved, namely to determine the increase in cognitive competence of children aged 5-6 years after using digital story telling and educational game applications in learning. Digital literacy activities carried out in the learning process in improving the cognitive abilities of early childhood in early childhood education are important where early childhood education that focuses on laying the foundation for physical growth and development, intelligence (thinking power, creativity, emotional intelligence, spiritual intelligence). This activity is carried out in collaboration with educators and parents of students. Educators and parents are examples (models) in their implementation. The process of activities to be carried out is as follows:

- Preparation of digital story telling and application of education games.

- Digital storytelling and education games applications are validated by education experts, and media experts. Based on the validation instrument, it was stated by education and media experts that digital story telling and education games applications were eligible for use in early childhood learning.

- Implementation of observations on the learning interests of early childhood students, totaling 15 people using digital story telling and education game applications, it is known that digital story telling and education games applications attract students' interest in learning.

- Implementation of operational trials begins with collaboration with early childhood and students' parents.

- Introduce and explain to teachers and parents about digital story telling \& education games in learning process.

- Teacher made link ZOOM Meeting and WA group consisting of parents who the children followed the program.

- Teacher made lesson plan according to learning theme of digital story telling and education games

- Researcher conduct pre-test to children who have joined the program.

- Teachers and parents assist children in using digital video storytelling and education games applications, doing play and learning activities together through Zoom Meeting and Offline Learning to be able to develop early childhood cognitive abilities.

- Reseacher made observation to teachers who conducted the Implementation of Digital Literacy Learning by Using Digital Story Telling and
Educational Game Applications to improve the cognitive abilities of children.

- Teachers made observation of Student Activities using Digital Story Telling and Educational Games several times.

- After treatment researcher conduct post-test to children who have joined the program.

This model is a digital literacy learning model using digital story telling media and educational game applications so that there is an increase in the cognitive abilities of children aged 5-6 years with the support of teachers and parents.

In this study, the design used was pre-experimental (one group pre-post-test design), namely a group of subjects who met the criteria of the researcher, before receiving treatment, a pre-test was carried out, then after receiving treatment a post-test was carried out to find out the consequences of the treatment. Research design is a design of how research is carried out. The research design used in this study was a one group pretest posttest design. In this design, before the treatment is given, the sample is given a pretest (initial test) and at the end of the study the sample is given a post-test (final test). This design is used in accordance with the objectives to be achieved, namely to determine the increase in cognitive competence of children aged 5-6 years after using digital story telling and educational game applications in learning.

The type of research used to determine the effectiveness of digital story telling media and educational game applications on the activities and learning outcomes of students is descriptive quantitative research. This method is a combination of two research procedures, namely qualitative and quantitative, where one method is more dominant than the other. The less dominant method is only used as a complement in obtaining data. The method that is more dominant in this research is qualitative and as a complementary method is quantitative. Researchers can find out whether digital story telling media and educational game applications are effective or not through data collection techniques such as observation and tests to students before and after learning. Data collection techniques used in this study are:

\subsection{Observation}

Observations are carried out in two ways, namely:

- Researchers directly observe learning activities carried out by teachers and students through zoom meetings with instruments that have been made. The observation instrument was made in the form of a learning description questionnaire to determine the learning process during the zoom meeting.

- Teacher observe the learning process by zoom or offline to find out the activities of students when 
using digital storytelling and educational games. The instrument for observing children's activities is in the form of a checklist questionnaire.

\subsection{Test}

Researchers collect information by submitting a number of questions in writing before and after being given treatment in the learning process to students to be answered.

\subsection{Documentation}

Researchers want to prove or strengthen the information obtained in the study such as the state of teachers and students during the learning process.

The participants in the model trial were 9 teachers and 45 students aged 5-6 years from three early childhood schools.

\section{RESULT \& DISCUSSION}

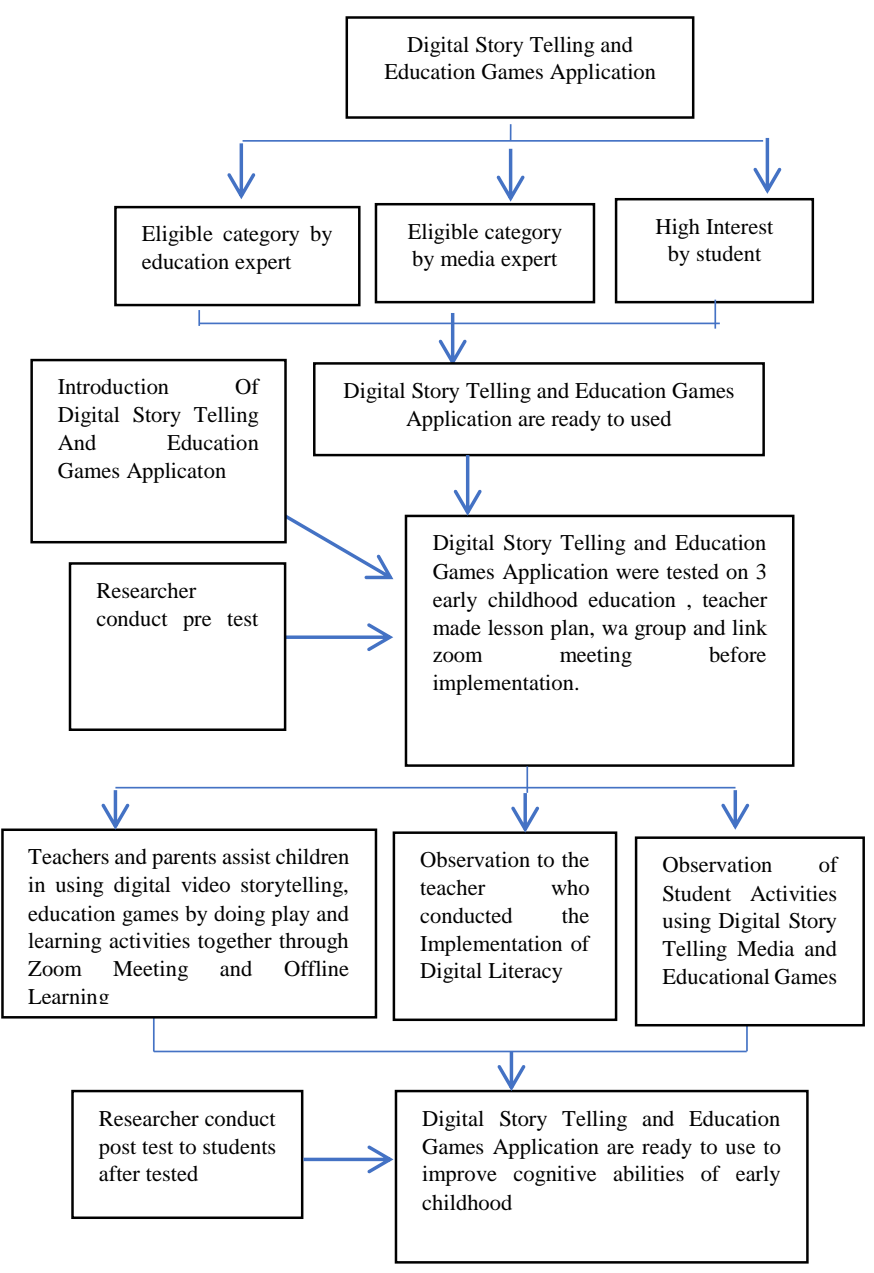

Figure 1. Chart of Developing digital story telling and Education Games Application

From the chart of Developing digital story telling and Education Games Application to improve early childhood cognitive ability, find the results:

\subsection{Result of validation of Media Expert}

Based on the results of the validation of the material, that the media in the form of digital story telling and game education applications obtained a score of $80 \%$ (Table 1) which means Good/Eligible to use in learning activity of early childhood. The results of this study are in accordance with the opinion of Levie and Lentz [14].

\subsection{Result of validation of Education Expert}

The validation by education experts from the learning aspect got a score of $80 \%$ in good category (Table 2). This means that the program created is in accordance with the learning objectives to be achieved. This is in accordance with the opinion of the expert Daryanto [7]. This can be interpreted that the material presented in the learning video and education game application is clear and appropriate in accordance with the material that has been determined by the teacher.

\subsection{Results of Observation of the Implementation of Digital Literacy Learning}

Results of Observation of the Implementation of Digital Literacy Learning by Using Digital Story Telling Media and Educational Game Applications to improve the cognitive abilities of children aged 5-6 years it is known that 10 (ten) indicators are observed in the implementation of Digital Literacy learning using Digital Story Telling Media and Game Applications Education in 7 learning segments is known to have been carried out well by teachers in 3 test sites, namely State Kindergarten of Pembina in Porsea, Early Childhood Education of Tamawi and Early Childhood Education of Al Barokah in Langkat Regency. The results of observations on the observed indicators are:

- The teacher has prepared the lesson plan according to the themes in the digital story telling media and educational game applications.

- The teacher has prepared communication media through the WA Group and Zoom Meeting Link and conveyed it to the parents of the students.

- The implementation of learning carried out by the teacher is in accordance with the steps contained in the lesson plan.

- Submission of material provided by the teacher to students is in accordance with lesson plan that has been prepared.

- Teacher and students interact with each other during the learning process

- Teacher has given questions to students regarding the Digital Story Telling story.

- Students have provided answers to questions posed by the teacher regarding Digital Story Telling stories.

- Students have given simple opinions regarding Digital Story Telling stories. 
Table 1. Result of validation of Media Expert

\begin{tabular}{|c|c|c|c|c|c|}
\hline NO & Rated Aspect & $\mathbf{S}$ & $\mathbf{N}$ & $\mathbf{P}(\%)$ & Validation \\
\hline 1. & Media presented is already visually attractive & 4 & 5 & $80 \%$ & Good \\
\hline 2. & The image presented is sharp / not broken & 4 & 5 & $80 \%$ & Good \\
\hline 3. & $\begin{array}{l}\text { The images presented in the story telling and game } \\
\text { education are in accordance with the material }\end{array}$ & 4 & 5 & $80 \%$ & Good \\
\hline 4. & The video presented is in accordance with the material & 4 & 5 & $80 \%$ & Good \\
\hline 5 . & $\begin{array}{l}\text { Educational game presented is in accordance with the } \\
\text { material }\end{array}$ & 4 & 5 & $80 \%$ & Good \\
\hline 6. & The typeface used is correct & 4 & 5 & $80 \%$ & Good \\
\hline 7. & The size and color of the letters used are correct & 4 & 5 & $80 \%$ & Good \\
\hline 8. & The language used is easy to understand & 4 & 5 & $80 \%$ & Good \\
\hline 9. & The harmonization of the use of colors is right & 4 & 5 & $80 \%$ & Good \\
\hline 10. & The layout arrangement is proportional & 4 & 5 & $80 \%$ & Good \\
\hline 11. & The voice/dubbing is clear & 4 & 5 & $80 \%$ & Good \\
\hline 12. & $\begin{array}{l}\text { The selection of sound effects / sound effects is } \\
\text { appropriate }\end{array}$ & 4 & 5 & $80 \%$ & Good \\
\hline 13. & Button usage is consistent/uniform & 4 & 5 & $80 \%$ & Good \\
\hline 14. & Speed in opening media/loading & 4 & 5 & $80 \%$ & Good \\
\hline 15. & The media used is easy to operate & 4 & 5 & $80 \%$ & Good \\
\hline 16. & Simplicity/cleanness of visual design appearance & 4 & 5 & $80 \%$ & Good \\
\hline 17. & Instructions for use are easy to understand & 4 & 5 & $80 \%$ & Good \\
\hline 18. & $\begin{array}{l}\text { The media presented is easy to use / according to the } \\
\text { ability level of students }\end{array}$ & 4 & 5 & $80 \%$ & Good \\
\hline 19. & $\begin{array}{l}\text { The use of media can attract the attention and curiosity of } \\
\text { students }\end{array}$ & 4 & 5 & $80 \%$ & Good \\
\hline 20. & $\begin{array}{l}\text { The use of media can increase the motivation/spirit of } \\
\text { students to learn }\end{array}$ & 4 & 5 & $80 \%$ & Good \\
\hline
\end{tabular}

Table 2. Result of validation of Education Expert

\begin{tabular}{|c|c|c|c|c|c|}
\hline NO & Rated Aspect & $\mathbf{S}$ & $\mathbf{N}$ & $\mathbf{P}(\%)$ & Validation \\
\hline 1. & $\begin{array}{l}\text { The accuracy of the material with the learning } \\
\text { objectives }\end{array}$ & 4 & 5 & $80 \%$ & Good \\
\hline 2. & $\begin{array}{l}\text { The suitability of the material with Core Competencies } \\
\text { and Basic Competencies }\end{array}$ & 4 & 5 & $80 \%$ & Good \\
\hline 3. & Complete of the material presented & 4 & 5 & $80 \%$ & Good \\
\hline 4. & Depth of material presented & 4 & 5 & $80 \%$ & Good \\
\hline 5. & Giving examples to explain the material & 4 & 5 & $80 \%$ & Good \\
\hline 6. & $\begin{array}{l}\text { The use of media can attract the interest and attention } \\
\text { of students }\end{array}$ & 4 & 5 & $80 \%$ & Good \\
\hline 7. & The concept presented is correct & 4 & 5 & $80 \%$ & Good \\
\hline 8. & $\begin{array}{l}\text { Submission of material has been coherent / has been } \\
\text { ordered }\end{array}$ & 4 & 5 & $80 \%$ & Good \\
\hline 9. & Suitability with the development of students & 4 & 5 & $80 \%$ & Good \\
\hline 10. & $\begin{array}{l}\text { Can make it easier for students to understand the } \\
\text { material }\end{array}$ & 4 & 5 & $80 \%$ & Good \\
\hline 11. & Can be used for independent study & 4 & 5 & $80 \%$ & Good \\
\hline 12. & Can increase motivation / enthusiasm for learning & 4 & 5 & $80 \%$ & Good \\
\hline 13. & Can increase the curiosity of students & 4 & 5 & $80 \%$ & Good \\
\hline 14. & Media can be used easily accompanied by parents & 4 & 5 & $80 \%$ & Good \\
\hline 15. & The language used is easy for students to understand & 4 & 5 & $80 \%$ & Good \\
\hline 16. & The sentences used are interactive & 4 & 5 & $80 \%$ & Good \\
\hline 17. & $\begin{array}{l}\text { The questions in the education game are related to the } \\
\text { story telling material }\end{array}$ & 4 & 5 & $80 \%$ & Good \\
\hline 18. & $\begin{array}{l}\text { Questions as a form of learning evaluation in } \\
\text { accordance with the basic competencies to be achieved }\end{array}$ & 4 & 5 & $80 \%$ & Good \\
\hline 19. & $\begin{array}{l}\text { The media used is able to provide students' learning } \\
\text { experiences }\end{array}$ & 4 & 5 & $80 \%$ & Good \\
\hline
\end{tabular}


- Teacher has made a conclusion from the Digital Story Telling story and conveyed it to the students after watching it.

- Teacher has asked students to work on educational games accompanied by parents at home after completing online learning activities.

This digital literacy learning activity is in accordance with what was stated by Keengwe \& Georgina [12] and Wekke \& Hamid [22].

\subsection{The results of Observation of Student Activities}

The results of Observation of Student Activities on the Application of Digital Literacy using Digital Story Telling Media and Educational Game Applications for 45 children carried out at the Pembina State Kindergarten in Porsea, Early Childhood Education of Tamawi and Early Childhood Education of AL Barokah in Langkat Regency:

Table 3. The results of Observation of Student Activities

\begin{tabular}{|c|c|c|c|c|c|}
\hline \multirow{2}{*}{ No } & \multirow{2}{*}{ Indicator } & $\begin{array}{c}\text { Pembina State } \\
\text { Kindergarten }\end{array}$ & $\begin{array}{c}\text { ECE of } \\
\text { Tamawi } \\
\end{array}$ & $\begin{array}{c}\text { ECE of Al } \\
\text { Barokah }\end{array}$ & \multirow{2}{*}{ Average } \\
\hline & & $\begin{array}{c}\text { Activity } \\
\text { Percentage }\end{array}$ & $\begin{array}{c}\text { Activity } \\
\text { Percentage }\end{array}$ & $\begin{array}{c}\text { Activity } \\
\text { Percentage }\end{array}$ & \\
\hline A. & $\begin{array}{l}\text { Fun learning } \\
\text { atmosphere }\end{array}$ & $84 \%$ & $81,33 \%$ & $78,67 \%$ & $81,33 \%$ \\
\hline B. & $\begin{array}{l}\text { Student's } \\
\text { responsibility }\end{array}$ & $81,33 \%$ & $76 \%$ & $78,67 \%$ & $78,67 \%$ \\
\hline C. & $\begin{array}{l}\text { Student's } \\
\text { confidence }\end{array}$ & $82,67 \%$ & $77,30 \%$ & $81,33 \%$ & $80,43 \%$ \\
\hline D. & $\begin{array}{l}\text { Children's activity } \\
\text { focus }\end{array}$ & $78,67 \%$ & $81,33 \%$ & $85,33 \%$ & $81,78 \%$ \\
\hline
\end{tabular}

From the Table 3, it can be seen that a pleasant learning atmosphere was felt by respondents who were given treatment with an average of 81.33 percent which was in the very good category, the responsibility of children in learning activities in digital literacy learning with an average of 78.67 percent are in the good category, children's confidence in learning activities in digital literacy learning with an average of 80.43 percent are in the good category, focus on children's activities when carrying out learning activities in digital literacy learning with an average of 81.78 percent is in the very good category.

Learning activities with the fullfill of indicators of good and fun learning atmosphere, good responsibility from children, good confidence in children in learning activities, and excellent focus of children on learning activities according to the opinion of Wina Sanjaya [19] which states that activity is not intended to be limited to physical activity, but also includes activities of a psychological nature such as mental activity. Sardiman [1] states that learning is doing and at the same time a process that makes students active. Therefore, the task of the teacher is to guide and direct students so that they can develop their talents and potential. In this case, it is the students who are active, act and must be active themselves

Based on the data on the children's pretest and posttest scores, it was found that there was a significant influence between digital literacy learning by using digital story telling and educational games on the cognitive development of children aged 5-6 years, this was seen from the increase from pre-test scores to post-test scores. before and after being given treatment, respondents in Pembina State Kindergarten in Porsea the pre-test score was 785 after getting treatment, it became 1105, respondents in Early Childhood of Tamawi the pre-test value was 760 after getting treatment, it became 1115, respondents in Early Childhood of AL Barokah the pretest value was 760 after getting treatment. to 1135 .

From the three test sites, namely at Pembina State Kindergarten in Porsea District, Toba Regency, Early
Childhood of Tamawi and Early Childhood of Al Barokah in Langkat Regency, it was found that $t$ value > $\mathrm{t}$ table, for Pembina State Kindergarten it was obtained (12.93 > 1.753) Early Childhood of Tamawi was obtained (17, $79>1.753)$, Early Childhood of AL Barokah was obtained $(18.65>1.753)$, then the research hypothesis is stated that digital literacy learning using digital storytelling media and educational games is effective for improving cognitive abilities in children aged 5-6 years.

The results of this study are in line with research conducted by Lisenbee \& Ford [16] on students at The Pittsburgh, explaining that the learning experience using the storytelling method, which is adapted to the characteristics of children, can increase motivation and performance for students who have a lack of mathematical ability, reading and writing skills. Storytelling can help teach students to listen to their language skills and help deepen the characteristics of stories and broaden their understanding. Kurniawati, Tirtayani, \& Darsana [13] explained that storytelling helps develop fluency, increases vocabulary, and helps remember words. 


\section{CONCLUSION}

The results of the development show that it is significant that the development of a Digital Literacy Model to Improve Cognitive Ability of Children aged 56 Years by using digital story telling and educational game applications is effective for improving cognitive abilities in children aged 5-6 years.

Therefore, digital literacy learning using digital storytelling media and educational game applications is very appropriate to be used in online learning by teachers in collaboration with parents so that learning innovations can occur and children do not feel bored and bored with the usual learning methods.

\section{REFERENCES}

[1] A.M, Sardiman. (2010). Interaksi dan Motivasi Belajar Mengajar [Teaching and Learning Interaction and Motivation]. Jakarta: PT. Raja Grafindo Persada

[2] Asmawati, Luluk. (2014). Perencanaan Pembelajaran PAUD [Early Childhood Learning Planning]. Bandung : Remaja Rosdakarya

[3] Barton, D. (2012). Participation, deliberate learning and discourses of learning online. Language and Education, 139-150.

[4] Borg \& Gall. (2003). Education Research. New York : Allyn and Bacon.

[5] Candra \& Puspita \& Adiyani. (2013).: Penggunaan internet pada anak- anak sekolah usia 6-12 tahun [Internet use in school children aged 6-12 years]. Journal UNAIR, Vol. 1 No. 2, Februari 2013.

[6] Common Sense Media. (2013). Zero to Eight Children's Media Use in America 2013. Common Sense Media.

[7] Daryanto. (2010). Media Pembelajaran, Peranannya Sangat Penting dalam Mencapai Tujuan Pembelajaran. [ Learning Media, Its Role is Very Important in Achieving Learning Goals]. Yogyakarta : Gava Media

[8] Gamire, E., \& Pearson, G. (2006). Tech tally: approaches to assessing technological literacy. (E. Gamire \& G. Pearson, Eds.), Literacy. Washington D.C., USA: The National Academics Press.

[9] Gilster, P. (1997). Digital Literacy. New York: Wiley.

[10] Harrison, E., \& McTavish, M. (2018). 'i’Babies: Infants' and toddlers' emergent language and literacy in a digital culture of iDevices. Journal of Early Childhood Literacy, Vol. 18 No. 2: 163-188.
[11] Kemendibud. (2014). Permendikbud no.146 tentang Kurikulum 2013 PAUD [Minister of Education and Culture Regulation No.146 concerning Early Childhood Education Curriculum]. Jakarta: Kementerian Pendidikan dan Kebudayaan.

[12] Keengwe, J., \& Georgina, D. (2012). The digital course training workshop for online learning and teaching. Education and Information Technologies, 17(4), 365-379. https://doi.org/10.1007/s10639011-9164-х

[13] Kurniawati, L. P. R., Tirtayani, L. A., \& Darsana, I. W. (2018). Pengaruh Metode Bercerita terhadap Kemampuan Menyimak Pada Anak Kelompok B di PAUD Gugus Anggrek Kecamatan Kuta Utara Tahun Pelajaran 2017/2018 [The Effect of Storytelling Method on Listening Ability in Group B Children at Early Childhood Education Gugus Anggrek, North Kuta District, 2017/2018] Jurnal Pendidikan Anak Usia Dini Undiksha, 6(1). https://doi.org/10.23887/paud.v6i1.15185

[14] Levie, W. H. and Lentz, R.. (1982). Effects of text illustrations: a review of research. Educational Communication and Technology Journal, 30: 195232

[15] Levy, B. A., Gong, Z., \& Hessel, S. (2005). Understanding print: Early reading development and the contribution of home literations of home literacy experiences. Experimental Child Psycology, 93, 63-93.

[16] Lisenbee, P. S., \& Ford, C. M. (2018). Engaging Students in Traditional and Digital Storytelling to Make Connections Between Pedagogy and Children's Experiences. Early Childhood Education Journal. https://doi.org/10.1007/s10643-017-0846-X

[17] Ministry of Education and Culture. (2018). Indonesia Educational Statistics In Brief = Ringkasan Statistik Pendidikan Indonesia 2018/2019. Jakarta: MOEC

[18] Mursid. (2015). Pengembangan Pembelajaran PAUD [Early Childhood Education Learning Development]. Bandung: Remaja Rosdakarya.

[19] Potter, W. J. (2004). Theory of media literacy: A cognitive approach. California: Sage Publications.

[20] Sanjaya, Wina. (2010). Strategi Pembelajaran Berorientasi Standar Proses Pendidikan [Educational Process Standard Oriented Learning Strategy] Jakarta : Prenada Media Group

[21] Sucipto \& Nuril, H. (2016). Pola bermain anak usia dini di era gadget siswa PAUD Mutiara Bunda Sukodono Sidoarjo [Early childhood play patterns in the era of gadgets for Early Childhood Education 
of Mutiara Bunda Sukodono Sidoarjo students]. Jurnal Ilmiah Fonema Vol. 3 No. 6: 274-347.

[22] Wekke, I. S. \& Hamid, S. 2013. Technology on Language Teaching and Learning : A Research on Indonesian Pesantren. Procedia - Social and Behavioral Sciences, 83, 585-589.

[23] Whitehurst, G. J. \& Lonigan, C. J. (2001). Emergent literacy: Development from prereaders to reader. Dalam S. B. Neuman \& Dickinson (eds), Handbook of early literacy research (pp. 11-28). New York: Guilford Press

[24] Widyastuti, D. A. R., Nuswantoro, R., \& Sidhi, T. A. P. (2016). Literasi Digital pada Perempuan Pelaku Usaha Produktif di Daerah Istimewa Yogyakarta [Digital Literacy for Women in Productive Entrepreneurs in the Special Region of Yogyakarta]. Jurnal Aspikom, Vol. 3 No. 1: 1-15. 